\title{
Plan for Sahel Rehabilitation
}

The International Union for Conservation of Nature and Natural Resources (IUCN) has called on African Governments, United Nations agencies, bilateral donors, and other nongovernmental aid organizations, to join forces to create a coordinated plan for the agricultural and environmental rehabilitation of the drought-stricken Sahel region of Africa.

At a press conference held at IUCN in Gland, IUCN President Dr Monkombu S. Swaminathan praised international efforts which have rushed emergency food-aid into the Sahel and other parts of Africa where up to 30 million Africans face starvation. However, he said that such food efforts are merely a short-term solution, dealing only with alleviating famine which is a symptom of much-deeper underlying resource-management problems.

He cited an IUCN report on the Sahel region* which shows that rainfall has been regularly decreasing in Africa, that there is no basis to predict when the drought will end, and that any strategy for the region must be based on the fact that drought will be a continuing factor. The IUCN report also shows that the natural productivity of arable land and rangeland has declined because of human pressure on vegetation, and that there has been serious deforestation which has created a fuel-wood shortage and, inevitably, has led to desertification. Stressing that IUCN is not suggesting that it has the answer to the Sahel's problems, Dr Swaminathan said it recognizes that many national and international organizations are making valuable individual contributions. IUCN wishes to add to those contributions, Dr Swaminathan said, pointing out that what is missing is overall coordination at the environmental level.

At a meeting of the IUCN Council held in Gland during 15 and 16 May 1985 , it was decided to set up an IUCN Task-force under the chairmanship of Dr Walter Lusigi, of Kenya. This task-force will develop proposals and recommendations leading to an integrated plan for the ecological and agricultural rehabilitation of the Sahel and other regions of Africa that are facing serious drought problems caused by the imbalance between population growth and food supply.

'One of our strategy's components is to look at the problem area by area - ecological area, political area-country by country, and try to develop agricultural rehabilitation plans based on sound principles of ecology or sustainable development,' Dr Swaminathan said. 'In other words, ecological rehabilitation and food production plans must be mutually supportive. This can be part of national conservation strategies for sustainable development.'

HRH the Duke of Edinburgh, IUCN's Vice-President, said he felt that the international community and African

* Desertification in the Sahel-Diagnosis and Proposals for IUCN's Response, 95 pp., illustr. World Conservation Centre (address below). governments were now more ready than formerly to accept the concept of coordinated environmental rehabilitation for Africa:

'Up to now, not only individual groupings [such as] United Nations organizations, but also national governments, havetended to want to make contributions to development in countries unilaterally or bilaterally. It's been very difficult to get coordinatioin because they want to get the kudos from having run a development project of some kind or another in the country-because they feel it promotes their ego or their status. So consequently, it's very difficult to achieve coordination in the conservation field. On top of that, up to relatively recentlyuntil the publication of the World Conservation Strategy - there was almost abysmal ignorance in most of these organizations about the problems of conservation, and about the implications of development for the actual environment. It's only now that we're getting into a disaster situation, that they're beginning to take this seriously and coordinate activities. Before, they didn't want to be coordinated, they didn't want to get resources moving in the right direction, because they didn't understand the problem. But I think gradually the situation is getting better.'

The IUCN Task-force, working with all appropriate national, bilateral, and international, agencies, will suggest methods of providing the basic needs of African people for food, fodder, and water, using techniques which are ecologically sound and economically sustainable.

In addition, an IUCN Task-Force on Population, headed by Dr Russell Peterson of the United States, will suggest methods of achieving harmony between population growth and resource management.

The IUCN Council also said there was an urgent need for the development of location-specific technologies for increasing food output in Africa, and felt that an Ecodevelopment Force of young professionals, properly structured and developed, could facilitate the development and transfer of economically and ecologically viable techniques. There is also a need for money to be devoted to solving the long-term problems of environmental enrichment in Africa. This suggests the need for an Environmental Rehabilitation Fund which would be used to implement effectively an integrated agricultural and ecological rehabilitation strategy on a nation-by-nation basis. In addition to such a fund, efforts at building local leadership, initiative, and institutions, are essential for success in converting the present calamity into an opportunity for opening up a new era in the economic development of Africa.

SANDRA WoOdS, News Editor IUCN Bulletin

World Conservation Centre

Avenue du Mont-Blanc

$\mathrm{CH}-1196$ Gland

Switzerland.

\section{'Guardians of the Trees'}

The Indian Society of Naturalists (INSONA) has taken the lead among South-east Asian countries in naming the schoolchildren as 'Guardians of the Trees'. The naming function was jointly organized by the Baroda Museum and INSONA to celebrate Earth Day and World Forestry Day on 21 March 1985. The Food and Agriculture Organization of the United Nations (FAO) has announced 1985 as the International Year of the Forest, but we feel that some responsibility to protect trees should rest with the "Guar- dians', who should bring cases of threats to the notice of INSONA and concerned authorities-especially the Conservators of the Forests - while noting that the 1985 World Environment Day (June 5th) theme was 'Youth, population, and environment'.

On our above occasion, awards were presented by Dr Jatin V. Modi, Mayor of the Baroda Municipal Corporation, to eighteen students who participated in a competition to locate giant Banyan (Ficus benghalensis) trees in the envi- 